\title{
The Psychological Consequences of the Holodomor in Ukraine ${ }^{1}$
}

\author{
Viktoriia Gorbunova \\ Zhytomyr Ivan Franko State University
}

\author{
Vitalii Klymchuk \\ Institute for Social and Political Psychology of National Academy of Educational Sciences of \\ Ukraine
}

\begin{abstract}
The Holodomor (derived from the Ukrainian words "to kill by starvation") (1932-33) was the largest famine in Ukrainian history. This article presents the results of a psychological study of personal attitudes to Holodomor events and of worldviews and behavioural strategies connected to famine exposure in the family histories of the survey participants. The results of a survey of 721 respondents showed (1) close connections between a respondent's pattern of keeping silent about traumatic events that occurred during the Holodomor and the extent of suffering that the respondent's family experienced during the Holodomor, and (2) close connections between the avoidance of Holodomor-related storytelling and a denial and devaluation of Holodomor events within families. The most common family behavioural strategies of descendants of Holodomor victims showed proper feeding, substantial food storage, and regular health check-in. The most common respondent attitudes comprised a distrust of authority, disappointment with the government, and a priority of family needs over community needs.
\end{abstract}

Keywords: psychological consequences, Holodomor, personal attitudes, behavioural strategy, family history, trauma, post-traumatic stress disorder, transgenerational trauma.

\section{INTRODUCTION}

Transgenerational trauma involves a transfer of trauma from the first generation of trauma survivors to the second and to further generations of descendants. Such trauma can include emotional reactions-for example, fear or helplessness - or even maladaptive behavioural patterns. Conversely, intergenerational trauma denotes an exchange of trauma-

\footnotetext{
1 This study was supported by the Holodomor Research and Education Consortium (HREC) and the Canadian Institute of Ukrainian Studies. We also acknowledge support from Laura Poole, MA, Clinical Psychology, International Disaster Psychology.
} 
related reactions between two proximate generations. Furthermore, historical, cultural, and collective traumas that connect with historical events can have impacts on social life, and affect many people, but they do not necessarily have a transgenerational effect. Transgenerational trauma can affect a small number of people or an entire group or community. Genocide, slavery, terrorism, and famine can result in transgenerational types of trauma. Here, we study the transgenerational trauma that resulted from the 1932-33 famine in Ukraine, known as the Holodomor.

The most common consequences of transgenerational trauma are psychological changes in future generations regarding worldview, values, self-attitudes, and behavioural strategies; also affected are the ways a subsequent generation resolves daily problems and builds relationships. The descendants of a trauma survivor will show emotional, cognitive, and behavioural patterns that can be connected to the original trauma.

The consequences of trauma are frequently explained through theoretical conceptualizations or case analyses, but they lack empirical research. Kellermann highlights four major models of trauma transmission: psychodynamic (unconscious trauma transmission through interpersonal relations), "family system" (enmeshment of trauma through communication within the family), socio-cultural (trauma transmission through parenting and role models), and biological (hereditary vulnerability to post-traumatic stress disorder) ("Transmission"). On the other hand, Bezo proposes five models and classifies each model according to its ability to explain trauma transmission. The first model is Bandura's social-cognitive theory of learning (behaviour and worldview attitudes may be transmitted through observation without critical estimate of influential events) (Bezo 128-30). The second model is based on Bronfenbrenner's ecological systems theory of the family (changes in actions and beliefs are transgenerationally transmitted through social and cultural reinforcement systems, for example, the family [microsystem] and the community [ecosystem]) (Bezo 130-33). The third model is associated with secondary (vicarious) traumatization, which links compassion toward survivors and a deep involvement in their traumatic experience (Bezo 133-34). The fourth model is related to the attachment theory and is based on the work of Bar-On and others. In this model genocide survivors are unwilling to talk about their traumatic experiences with their offspring, but demonstrate consequences of their trauma in their behaviour and in their treatment of children. Consequently, their children develop disorganized attachment patterns and problematic behaviours (Bezo 134-36). The fifth model is based on the shattered assumptions theory of Janoff-Bulman, in which trauma breaks or "shatters" a fundamental human assumption that the world is benevolent, and the self is worthy (Bezo 136-37). Bezo individually and in co-authorship with Maggi explains transgenerational influence through the transmission of insecure 
attachment and social learning (Bezo; Bezo and Maggi, "Living" and "Intergenerational Perceptions"). Some recent studies of different traumas support the idea that intergenerational transmission (from parents to children) of traumas' consequences can be mediated by parenting style and psychological maltreatment by caregivers (Field et al.; Palosaari et al.).

We see three common types of generational trauma transmission. The first type of trauma transmission over generations is socio-cultural. It is a transfer of interactive and behavioural patterns as well as worldview attitudes at interpersonal, cultural, and social levels through communication, socialization, observation/imitation, compassion, child treatment, and community rules. The second type of generational trauma transmission is an epigenetic transmission, where trauma is inherited by descendants. Such inheritance is derived from the nervous system of parents who were exposed to traumatic events. The third type of generational trauma transmission involves the unconscious reproduction of parental behaviours and attitudes (this type of trauma transmission is related to socio-cultural and/or neurobiological trauma transmission).

Often, the rigorous evidence base of generational trauma transmission is a feature of socio-cultural (e.g., studies by Bezo; Bezo and Maggi, "Living"; Klicperová et al.) and neurobiological (e.g., Kellermann, "Epigenetic Transmission"; Skelton et al.) research, as well as works that consider transgenerational trauma to be caused by vicarious traumatization (where symptoms of trauma are caused not by a traumatic event, but by empathic engagement with traumatized persons). Although vicarious traumatization leads to mental problems and psychological issues, it is not generationally "transmitted" (Baranowsky, et al.; Bryant et al.; Rieder and Elbert; Ahmadzadeh and Malekian). Empirical explorations of the unconscious transmission of trauma are difficult; examples include the transgenerational script (Noriega), the ancestor syndrome (Schutzenberger), and projective identification (Rowland-Klein and Dunlop). Although data derived from the unconscious transmission of trauma typically do not agree with existing research data on post-traumatic stress disorder, approaches to this variant provide strong qualitative descriptions of responses, behavioural patterns, beliefs, and attitudes.

This article describes a study of the psychological consequences and transgenerational outcomes of the Holodomor, one of the most traumatic events in the history of Ukraine. The term "Holodomor" in Ukrainian historiography denotes a famine provoked by the Soviet authority in 193233. The Holodomor was the largest man-made famine in Ukraine's history (the number of victims reached 4-7 million, according to different calculations). Other mass famines inside and outside Ukraine (for instance in the Kuban and Volga regions) were also caused by the Stalin regime, and aimed at the destruction of Ukrainians, but they are mostly defined as man- 
made famines ("shtuchnyi holod"). On the other hand, much historical evidence indicates that the Holodomor was purposely organized to accomplish Ukrainian genocide (see Bilinsky). The Holodomor has been recognized in more than 20 countries around the world as an attempt to eliminate the Ukrainian people. Data updates for the Holodomor and information about current conferences, publications, and initiatives, can be found at the National Museum of the Holodomor-Genocide (http://memorialholodomor.org.ua/eng).

Masliuk describes five factors of the Holodomor that provoked psychological changes that could have been inherited: information deprivation (people did not know the extent of the starvation and the real aims of the Soviet government), confinement (people did not have the flexibility to escape from their regions), famine (there was insufficient food for survival), a ban on spiritual practices (people were pressed to maintain only communist ideology), and the destruction of traditions (for example, the tradition of mutual help and support). Hornostai referred to the Holodomor as the biggest trauma in the history of Ukraine, and cited four factors that made the collective trauma grave: the large number of people traumatized by their inability to obtain sufficient food, the high level of injustice, the inability of people to resist, and the limitations of emotional response. Hornostai calls the Holodomor the biggest trauma in the history of Ukraine.

Although historical and cultural studies of the Holodomor are prevalent, there is a lack of extensive psychological studies of the consequences of the Holodomor to following generations. As a result, Sysyn does not mention any work on this topic in his "Thirty Years of Research on the Holodomor: A Balance Sheet." The one exception is the research of Obushnyi and Voropaieva, which surveyed 1000 participants who were between the ages of 1-7 years-old during the Holodomor. This study showed higher levels of conformism, anxiety, phobias, behaviour avoidance, and inner conflicts in persons subjected to the Holodomor than in persons who at the time of the Holodomor lived in territories free of this trauma.

Studies of the psychological consequences of the Holodomor in subsequent generations usually have small sample sizes, lack empirical exploration, or derive only theoretical conclusions and generalizations. Most studies have focused on changes in behaviour, moral attitudes, values, and worldviews of descendants of Holodomor victims. Behavioural features of Holodomor descendants include irrational stockpiling/hoarding of excessive food supplies, an inability to discard unwanted and unneeded items, an extreme reverence for food, overeating, and a permanent state of anxiety regarding survival (Bezo and Maggi, "Intergenerational Impact"). In terms of personal values, Reva observed that Holodomor descendants have a national inferiority complex (for example, they compare their personal 
abilities unfavourably with the abilities of Russians), a permanent fear of defeat, and low levels of aspiration. Holodomor descendants lack male role models to provide male guidance and support, and with whom they could share experiences and values (Bezo and Maggi, "Intergenerational Impact" and "Intergenerational Perceptions"). There is evidence among Holodomor descendants to suggest the existence of a Stockholm syndrome (a psychological alliance with the captors during captivity) between the Ukrainian people and the aggressor, which results in a deformation of worldview, the creation of a Soviet values system originating from a fear of using the Ukrainian language, and an impulse to appear loyal to any type of national identity (Reva). On the other hand, data also show that religious people, who forgive murderers and pray for the victims, have the most constructive attitudes toward themselves and to life, and these attitudes can be passed to offspring (Hrydkovets').

An avoidance of discussing the Holodomor in conversation should be noted separately, since this pattern is not so much inherited as caused by the Soviet regime. Bezo writes that at least one member from each of the familyparticipants during his research remembered the "closed status" of this subject during the Soviet period.

The psychological consequences of the Holodomor on individuals in succeeding generations showed cognitive (ways of thinking) and behavioural (ways of behaving) patterns. Cognitive consequences were associated with how life is interpreted and how behavioural consequences affect coping strategies and reactions to the world that are determined by the worldview. The inheritance of emotional instability (a tendency to feel fear, horror, sadness, indifference to others, shame, anger), which can lead to a deficit of mental well-being (resulting in general stress, anxiety, and alcohol and drug abuse), should be considered separately. These consequences can be difficult to divide into psychological outcomes and mental health issues (which have neurobiological components), but they have a tendency to decrease in intensity from generation to generation (Bezo; Bezo and Maggi, "Intergenerational Perceptions").

Similar points are presented in the studies of other transgenerational traumas. For example, Kellermann cites disruptive changes in self, cognition, affectivity, and interpersonal functioning in descendants of Holocaust survivors ("Transmission"). DeGruy describes a particular kind of intergenerational trauma, "the post-traumatic slave syndrome," a set of behaviours and beliefs (e.g., a general self-destructive outlook, learned helplessness, distorted self-concept) common in African Americans, whose ancestors suffered from a long history of slavery and racism. The postCommunist syndrome, developed from the time of the Soviet Union, is a pattern of symptoms that evoke specific manifestations of immorality/incivility, and a lack of civic culture and civic virtues in regard to 
tragedies (Klicperová et al.; Klicperová-Baker). A dependence on transmitted worldviews and attitudes after trauma is also shown in the qualitative study of Lev-Wiesel. Lev-Wiesel presents three research cases with three different types of traumatic events experienced by the first generation-genocide, a long stay in a transit immigration camp, and a forcible relocation from the homeland. Representatives of the second and third generations feel sadness (as they are encouraged "To remembernever forget"), anger (because they cannot return to their homeland), and shame (regarding their social status).

Other researchers have written about post-genocide mental health outcomes (such as depressive, aggressive, and anxiety symptoms, child conduct problems, hyperactivity, and peer problems) in the second generation of individuals afflicted with post-traumatic stress disorder (PTSD): PTSD afflicted survivors of World War II (Yehuda et al.), the Vietnam war (Rosenheck and Thomson), Holocaust genocide (Flory et al.; Baranowsky et al.), the Croatian war of independence (Klain and Pavić), Rwandan genocide (Rieder and Elbert), and the Isfahan war (Ahmadzadeh and Malekian).

The commonalities of transgenerational psychological outcomes suggest their joint nature in addressing socio-cultural and neurobiological mechanisms of their transmission (they are transmitted epigenetically and have a direct impact on mental health as vicarious traumatization). In psychological studies, socio-cultural transmission plays the main role because the immediate neurobiological trauma responses, such as a reaction or arousal in the amygdala in response to cortisol, are connected with epigenetic transmissions, which are more crucial for mental health outcomes than psychological consequences. Vicarious traumatization is not related to transmission mechanisms as such because it has a direct impact on the mental health and well-being of only those individuals who come in contact with trauma survivors.

\section{METHODOLOGY}

Trauma transmission is not well defined or well described in existing research. Table 1 portrays a research model that can be used to analyze the psychological consequences of transgenerational trauma. The model enables us to clarify the mechanism(s) of trauma transmission and to develop a research plan to excrete and analyze different types of psychological consequences. 


\section{Table 1. Research model of psychological consequences of the transgenerational trauma caused by the Holodomor of 1932-33.}

\begin{tabular}{|c|c|c|c|c|}
\hline $\begin{array}{l}\text { DIAGNOSTIC } \\
\text { CRITERIA OF PTSD } 2\end{array}$ & $\begin{array}{l}\text { MECHANISMS } \\
\text { OF TRAUMA } \\
\text { TRANSMISSION }\end{array}$ & $\begin{array}{l}\text { TYPE OF } \\
\text { CONSEQUENCES }\end{array}$ & CHANGES & $\begin{array}{l}\text { DIAGNOSTIC } \\
\text { SECTION in the } \\
\text { interviews }\end{array}$ \\
\hline Exposure & - & - & - & $\begin{array}{l}\text { "Holodomor- } \\
\text { related family } \\
\text { history" }\end{array}$ \\
\hline $\begin{array}{l}\text { Internal/external } \\
\text { avoidance } \\
\text { (thoughts, } \\
\text { feelings/objects, } \\
\text { places) }\end{array}$ & socio-cultural & psychological & $\begin{array}{l}\text { attitudes } \\
\text { toward } \\
\text { events/ } \\
\text { storytelling }\end{array}$ & $\begin{array}{l}\text { "Personal } \\
\text { attitude to the } \\
\text { Holodomor"/ } \\
\text { "Holodomor- } \\
\text { related } \\
\text { storytelling } \\
\text { behaviour } \\
\text { within the } \\
\text { family" }\end{array}$ \\
\hline $\begin{array}{l}\text { Negative changes in } \\
\text { mood/cognitions } \\
\text { (amnesia, negative } \\
\text { beliefs/emotional } \\
\text { state, distorted } \\
\text { blame, loss of } \\
\text { interest, social } \\
\text { detachment, low } \\
\text { positive emotions) }\end{array}$ & socio-cultural & psychological & $\begin{array}{l}\text { worldview } \\
\text { attitudes } \\
\text { and } \\
\text { behavioural } \\
\text { strategies }\end{array}$ & $\begin{array}{l}\text { "Family } \\
\text { worldview } \\
\text { attitudes in } \\
\text { regard to the } \\
\text { Holodomor and } \\
\text { behavioural } \\
\text { strategies" }\end{array}$ \\
\hline $\begin{array}{l}\text { Re-experiencing } \\
\text { (intrusions, } \\
\text { nightmares, } \\
\text { flashbacks, } \\
\text { emotional and } \\
\text { physical reactions) }\end{array}$ & \multirow[t]{2}{*}{$\begin{array}{l}\text { epigenetic, with } \\
\text { a direct impact } \\
\text { on mental } \\
\text { health } \\
\text { (vicarious } \\
\text { traumatization) }\end{array}$} & \multirow[t]{2}{*}{ neurobiological } & \multirow[t]{2}{*}{$\begin{array}{l}\text { physical } \\
\text { health and } \\
\text { mental } \\
\text { health }\end{array}$} & \multirow[t]{2}{*}{$\begin{array}{l}\text { beyond study } \\
\text { topic }\end{array}$} \\
\hline $\begin{array}{l}\text { Hyperarousal } \\
\text { (aggression/ } \\
\text { irritability/anger, } \\
\text { recklessness/self- } \\
\text { destructiveness, } \\
\text { hypervigilance, } \\
\text { exaggerated startle } \\
\text { response, difficulty } \\
\text { concentrating/ } \\
\text { sleeping) }\end{array}$ & & & & \\
\hline
\end{tabular}

2 According to the American Psychiatric Association's Diagnostic and Statistical Manual of Mental Disorders (DSM-5). 
Post-traumatic stress disorder (PTSD) was the starting point for developing our research model and its diagnostic criteria (Diagnostic and Statistical Manual of Mental Disorders [DSM-5] - a taxonomic and diagnostic tool published by the American Psychiatric Association). PTSD is a mental health disorder with specific symptoms that follows exposure to one or more traumatic events. Individuals who suffer from PTSD persistently avoid trauma-related thoughts and feelings, and try to evade objects and places that have connections with traumatic events. However, the traumatic events previously experienced are commonly re-experienced by trauma survivors in the forms of intrusive distressing memories, nightmares, flashbacks, emotions, and physical reactions. In addition, individuals with PTSD experience negative changes in mood and cognition, hold negative beliefs and have negative expectations, and demonstrate distorted blame, loss of interest, social detachment, and few positive emotions. Symptoms of PTSD include hyperarousal (marked alterations in arousal and reactivity) that manifests as aggression, irritability, anger, recklessness, and selfdestructiveness. Individuals with PTSD find it difficult to concentrate and often experience sleeping disturbances. Appearance of the symptoms described above plus an exposure to life-threatening traumatic events comprise the diagnostic criteria of PTSD according to DSM-5. As famine is a traumatic event with deadly outcomes, many survivors of the Holodomor must have suffered PTSD symptoms.

The question essential to our research model is: how did PTSD symptoms pass through generations? Studies of the neurobiological impact of trauma have reported that changes in the brain and neural system caused by trauma can be passed from the original recipients of the trauma to descendants (Kellermann, "Epigenetic Transmission"; Skelton et al.). Thus, offspring of traumatized individuals can experience trauma and hyperarousal to an extent that is damaging to their mental health. Although there is still little strong evidence for the epigenetic transmission of trauma in humans, some evidence has been suggested in animal models (Yehuda and Lehrner). In any case, neurobiological consequences are far beyond the scope of our study. Here we ask if the consequences of personal and societal trauma can reach succeeding generations by socio-cultural transmission. That is, whether traumatic worldview attitudes and traumatic behavioural strategies can be passed to succeeding generations via copied behaviour, conversations, non-verbal reactions, and decision-making styles. In addition, a later generation might inherit attitudes toward Holodomor-related events through the storytelling of a previous generation.

As the result of a literature review and observations made during focus groups, we derived three hypotheses. (1) The more extensive the suffering experienced by families during the Holodomor, the less inclined they are to tell stories about the Holodomor. (2) The fewer the Holodomor-related 
stories told by families, the more negative are the attitudes toward Holodomor-related topics. (3) Of all the Holodomor-related worldview attitudes and behavioural strategies present in families, attitudes and behaviour concerning food, weight, health, and life-saving are the most widespread.

The research model showed connections between (i) the diagnostic criteria of PTSD; (ii) the most obvious transmission mechanisms for each criterion through generations; (iii) the consequences of the action of each mechanism; (iv) changes in attitude and behaviour, and (v) diagnostic sections in the structured interviews of participants (see the Appendix). Thus, the exposure to a traumatic event is revealed through the diagnostic section "Holodomor-related family history." Two subsequent diagnostic sections of the interview ("Personal attitude to the Holodomor" and "Holodomor-related storytelling behaviour within the family") show how internal and external avoidance of traumatic experiences can pass from ancestors to descendants. Unwillingness to think, talk, and learn about the Holodomor, a refusal to honour the victims of the Holodomor, and a predisposition to believe in the Soviet version of the causes of the Holodomor can be consequences of PTSD diagnostic criteria, such as internal and external avoidance of traumatic experiences. The final diagnostic section "Family worldview attitudes in regard to the Holodomor and behavioural strategies" shows that worldview attitudes and behavioural strategies in families can be a result of the socio-cultural transmission of PTSD symptoms - such as negative alterations in mood and cognition-from ancestors to descendants.

The research was performed with a structured interview method developed in Google Forms for online use, and the information was shared on Facebook and via personal mail (see the Appendix). The survey was launched in January 2017 and was open for one year.

It is important to mention that the term "Holodomor" was not in use in the Soviet period. Our ancestors could not talk about Holodomor events using this word. The subjects of famine, Soviet grain procurement plans, and Stalin's actions were discussed without using the word "Holodomor." However, the term "Holodomor" is currently recognized in Ukraine, and its meaning is clearly understood by contemporary Ukrainian citizens. For that reason, we decided to use the term "Holodomor" in our project.

Project participants took part in an interview that involved four diagnostic sections and one information section (see the Appendix). The first diagnostic section, "Holodomor-related family history," investigated whether the participant's family lived in a territory affected by the Holodomor and whether there were Holodomor victims in the family. This section of the interview also looked at the extent of family members' suffering ("One or more of my family members died," "All my family 
members survived but starved and suffered a lot," "Our neighbours/distant relatives suffered or died," "My family starved, but not so much that it threatened their life," "My family experienced no suffering"). The second diagnostic section, "Holodomor-related storytelling behaviour within the family," asked respondents to describe their experiences of family storytelling regarding the Holodomor, the frequency of such storytelling and the acceptability of such storytelling from "often and in detail" to "family stories exist but were not retold" with additional options for cases in which the participant knows nothing about Holodomor-related family stories or knows for sure that there are no Holodomor-related family stories. The third diagnostic section of the interview, "Personal attitudes to the Holodomor," sought information about participants' positions regarding the avoidance or devaluation of Holodomor-related topics/actions, and vice versa. The fourth diagnostic section, "Family worldview attitudes in regard to the Holodomor and behavioural strategies," inquired about participants' behavioural strategies and worldview attitudes and the relevance of these attitudes to other family members.

The statements for the two final sections of the interview were drafted on the basis of preliminary work that asked focus groups (92 individuals) to share Holodomor-related experiences and questioned them about persistent attitudes and behaviours related to these experiences. After grouping and generalization, these attitudes and behaviours were included in the pilot version of the questionnaire, which was amended based on the feedback from individuals in the focus groups.

The information section of the interview contained data regarding gender, age, current family residences, and family residences during the Holodomor. Data were subjected to descriptive statistics, frequency analysis, and correlation analysis. Study participants included 721 persons-81\% female and 19\% male-some from different regions of Ukraine and some from foreign countries (U.K., Georgia, Canada, U.S.A., Russia, Israel, Germany, Norway, Portugal). ${ }^{3}$ The average age of individuals who completed the questionnaire was 38.7 years; questionnaire participants comprised the following age ranges: 17-29 years (146), 30-39 years (239), 40-49 years (214), 50-59 years (101), and 60-69 years (21). The interview did not collect information about a participant's place in the generation line, but the overall age range indicates that no participant belonged to the first generation of Holodomor survivors. Representatives of second, third, and fourth generations of Holodomor survivors took part in the study.

Participants whose families lived in the territory that suffered from the

\footnotetext{
${ }^{3}$ More than 1000 individuals took part in the survey, but only participant data that were complete, with no missing answers, were selected for analysis.
} 
Holodomor comprised $75 \%$ of the cases studied; $6 \%$ of the participants did not know the location of their family at the time of the Holodomor; the ancestors of $19 \%$ of the interviewees did not live in the famine zone. Some of the answers to the questionnaire described unique cases; for example, "My family lived near affected territory." Among participants whose families lived in the Holodomor-impacted territory, 45\% lost at least one family member, 79\% mentioned life-threatening suffering of neighbours or distant relatives, $30 \%$ reported that the family starved without danger to life, and $4 \%$ cited an absence of any kind of suffering (Table 2 ).

Table 2. Holodomor-related family history of participants whose families lived in Holodomor-impacted territory.

\begin{tabular}{|c|c|c|c|c|c|c|c|c|c|c|}
\hline & \multicolumn{2}{|c|}{$\begin{array}{l}\text { One or more } \\
\text { of my family } \\
\text { members } \\
\text { died during } \\
\text { the } \\
\text { Holodomor }\end{array}$} & \multicolumn{2}{|c|}{$\begin{array}{l}\text { All my } \\
\text { family } \\
\text { members } \\
\text { survived } \\
\text { during the } \\
\text { Holodomor } \\
\text { but starved } \\
\text { and } \\
\text { suffered a } \\
\text { lot }\end{array}$} & \multicolumn{2}{|c|}{$\begin{array}{l}\text { Our } \\
\text { neighbours/ } \\
\text { distant } \\
\text { relatives } \\
\text { suffered or } \\
\text { died during } \\
\text { the } \\
\text { Holodomor }\end{array}$} & \multicolumn{2}{|c|}{$\begin{array}{l}\text { My family } \\
\text { was } \\
\text { starving } \\
\text { during the } \\
\text { Holodomor, } \\
\text { but not so } \\
\text { much that } \\
\text { it } \\
\text { threatened } \\
\text { their life }\end{array}$} & \multicolumn{2}{|c|}{$\begin{array}{l}\text { My family } \\
\text { experienced } \\
\text { no suffering } \\
\text { from the } \\
\text { Holodomor }\end{array}$} \\
\hline & $n$ & $\%$ & $n$ & $\%$ & $n$ & $\%$ & $n$ & $\%$ & $n$ & $\%$ \\
\hline Yes & 244 & 45 & 252 & 47 & 428 & 79 & 164 & 30 & 22 & 4 \\
\hline No & 164 & 30 & 203 & 37 & 13 & 2 & 283 & 52 & 477 & 88 \\
\hline $\begin{array}{l}\text { I don't } \\
\text { know }\end{array}$ & 134 & 25 & 87 & 16 & 101 & 19 & 95 & 18 & 43 & 8 \\
\hline Total & 542 & 100 & 542 & 100 & 542 & 100 & 542 & 100 & 542 & 100 \\
\hline
\end{tabular}

\section{RESULTS}

Holodomor-related storytelling behaviour within families was reported to have the following patterns. The rare retelling of Holodomor-related stories was reported by $63 \%$ of the participants whose ancestors lived in the Holodomor area. In summary, however, participants whose families had lived in the stricken areas (84\%) reported either an absence of story retelling ("I know nothing about Holodomor-related family stories," "Holodomor-related family stories exist but were not retold") or rare storytelling ("Holodomor-related family stories were retold but not often"). 
Only $16 \%$ of the participants reported frequent and detailed Holodomor storytelling within families (Table 3 ).

Table 3. Holodomor-related family storytelling behaviour among participants from Holodomor-stricken areas.

\begin{tabular}{|c|c|c|c|c|c|c|c|c|c|c|}
\hline \multirow[t]{2}{*}{$\begin{array}{l}\text { My family } \\
\text { lived in the } \\
\text { Holodomor } \\
\text { area }\end{array}$} & \multicolumn{2}{|c|}{$\begin{array}{l}\text { I know for } \\
\text { sure that } \\
\text { there are no } \\
\text { Holodomor- } \\
\text { related } \\
\text { family } \\
\text { stories }\end{array}$} & \multicolumn{2}{|c|}{$\begin{array}{l}\text { I know } \\
\text { nothing } \\
\text { about } \\
\text { Holodomor- } \\
\text { related } \\
\text { family } \\
\text { stories }\end{array}$} & \multicolumn{2}{|c|}{$\begin{array}{l}\text { Holodomor- } \\
\text { related } \\
\text { family } \\
\text { stories exist } \\
\text { but were } \\
\text { not retold }\end{array}$} & \multicolumn{2}{|c|}{$\begin{array}{l}\text { Holodomor- } \\
\text { related } \\
\text { family } \\
\text { stories } \\
\text { were retold } \\
\text { but not } \\
\text { often }\end{array}$} & \multicolumn{2}{|c|}{$\begin{array}{l}\text { Holodomor- } \\
\text { related } \\
\text { family } \\
\text { stories } \\
\text { were retold } \\
\text { often and in } \\
\text { detail }\end{array}$} \\
\hline & $n$ & $\%$ & $N$ & $\%$ & $n$ & $\%$ & $n$ & $\%$ & $n$ & $\%$ \\
\hline Yes & 3 & 1 & 42 & 8 & 65 & 12 & 339 & 63 & 93 & 16 \\
\hline No & 38 & 28 & 55 & 40 & 8 & 6 & 26 & 19 & 9 & 7 \\
\hline $\begin{array}{l}\text { I don't } \\
\text { know }\end{array}$ & 4 & 9 & 21 & 49 & 4 & 9 & 14 & 33 & 0 & 0 \\
\hline Total & 45 & 38 & 118 & 97 & 77 & 27 & 379 & 115 & 102 & 24 \\
\hline
\end{tabular}

The correlation coefficients between the kind of suffering (generational closeness between participants in the study and relatives who experienced the Holodomor; grade of starvation and distress) and the level of storytelling (absence of story retelling to frequent story retelling) among descendants of relatives who lived in Holodomor-stricken areas point to some strong connections. The first is a meaningful direct connection between storytelling behaviour and the deaths of neighbours or distant relatives $(r=0,2 ; p=0,000)$, meaning that the people who lost someone who was not close to them were retelling Holodomor-related stories more frequently than people who had lost someone close to them. The second two are meaningful inverse connections between storytelling behaviour and suffering without threat to life $(r=-0,16 ; p=0,000) /$ absence of suffering $(r=-0,1322 ; p=0,002)$. It appears, contrary to the statement above on storytelling and death in the family, that people whose suffering was not critical have a tendency to talk about the Holodomor less often (Table 4). 
Table 4. Correlation between the kind of suffering and the level of Holodomor-related storytelling behaviour among participants from Holodomor-stricken areas.

\begin{tabular}{|c|c|c|c|c|c|c|c|c|c|c|}
\hline & \multicolumn{2}{|c|}{$\begin{array}{l}\text { One or more } \\
\text { of my family } \\
\text { members } \\
\text { died during } \\
\text { the } \\
\text { Holodomor }\end{array}$} & \multicolumn{2}{|c|}{$\begin{array}{l}\text { All of my } \\
\text { family } \\
\text { members } \\
\text { survived } \\
\text { during the } \\
\text { Holodomor } \\
\text { but starved } \\
\text { and suffered a } \\
\text { lot }\end{array}$} & \multicolumn{2}{|c|}{$\begin{array}{l}\text { Our } \\
\text { neighbours/ } \\
\text { distant } \\
\text { relatives } \\
\text { suffered or } \\
\text { died during } \\
\text { the } \\
\text { Holodomor }\end{array}$} & \multicolumn{2}{|c|}{$\begin{array}{l}\text { My family } \\
\text { starved } \\
\text { during the } \\
\text { Holodomor, } \\
\text { but not so } \\
\text { much that it } \\
\text { threatened } \\
\text { their life }\end{array}$} & \multicolumn{2}{|c|}{$\begin{array}{l}\text { My family } \\
\text { experienced } \\
\text { no suffering } \\
\text { from the } \\
\text { Holodomor }\end{array}$} \\
\hline & $r$ & $p$ & $r$ & $p$ & $r$ & $P$ & $r$ & $p$ & $r$ & $p$ \\
\hline $\begin{array}{l}\text { Level of } \\
\text { storytelling }\end{array}$ & 0,08 & 0,054 & $-0,02$ & 0,591 & 0,22 & 0,000 & $-0,16$ & 0,000 & $-0,13$ & 0,002 \\
\hline
\end{tabular}

Personal attitudes to the Holodomor have distinctive, territory-related differences. The most common avoidance attitude was "I don't attend events dedicated to the Holodomor," which was chosen as a statement closest to one's own behaviour, actions, and beliefs in $155(21,5 \%)$ study participants; 349 (48\%) participants indicated that this statement was partially close to their behaviour, actions, and beliefs. Participants who did not know about the place of their ancestors' residence, tended to report negative attitudes (in terms of avoidance or devaluation of Holodomor-related topics and actions) more than study participants who did know about the place of their ancestors' residence. This was relevant for every diagnostic statement in this section of the interview, with one exception: "I don't read about the Holodomor and am not interested in this topic" (Table 5). 
Table 5. Personal attitudes to the Holodomor.

\begin{tabular}{|c|c|c|c|c|c|c|c|c|c|c|}
\hline \multirow{2}{*}{\multicolumn{2}{|c|}{$\begin{array}{l}\text { My family lived in the Holodomor } \\
\text { area } \\
\text { Closeness of the statement to } \\
\text { behaviour, actions, and beliefs }\end{array}$}} & \multicolumn{2}{|l|}{ Yes } & \multicolumn{3}{|c|}{ No } & \multicolumn{4}{|c|}{ I don't know } \\
\hline & & \multirow{2}{*}{$\frac{\stackrel{0}{0}}{0}$} & \multirow{2}{*}{ 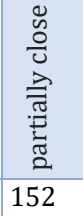 } & \multirow{2}{*}{$\begin{array}{l}\underset{\pi}{\vec{\pi}} \\
380\end{array}$} & \multirow{2}{*}{$\begin{array}{l}\stackrel{D}{0} \\
\frac{O}{U}\end{array}$} & \multirow{2}{*}{ 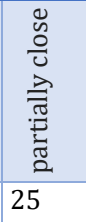 } & \multirow{2}{*}{$\begin{array}{l}\substack{\pi \\
\sum_{\pi}} \\
109\end{array}$} & \multirow{2}{*}{$\begin{array}{l}\stackrel{\Xi}{\cup} \\
\stackrel{\circlearrowright}{\cup} \\
4\end{array}$} & \multirow{2}{*}{ 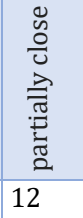 } & \multirow[b]{2}{*}{27} \\
\hline \multirow{2}{*}{$\begin{array}{l}\text { I avoid conversations on } \\
\text { Holodomor-related topics }\end{array}$} & $n$ & & & & & & & & & \\
\hline & $\%$ & 1,85 & 28,04 & 70,11 & 1,47 & 18,38 & 80,15 & 9,30 & 27,91 & 62,79 \\
\hline \multirow{2}{*}{$\begin{array}{l}\text { I think that talking about } \\
\text { Holodomor-related topics } \\
\text { and remembering those } \\
\text { events is not a good idea }\end{array}$} & $n$ & 12 & 121 & 409 & 2 & 21 & 113 & 4 & 11 & 28 \\
\hline & $\%$ & 2,21 & 22,32 & 75,46 & 1,47 & 15,44 & 83,09 & 9,30 & 25,58 & 65,12 \\
\hline \multirow{2}{*}{$\begin{array}{l}\text { I do not read about the } \\
\text { Holodomor and am not } \\
\text { interested in this topic }\end{array}$} & $n$ & 20 & 182 & 340 & 5 & 41 & 90 & 0 & 19 & 24 \\
\hline & $\%$ & 3,69 & 33,58 & 62,73 & 3,68 & 30,15 & 66,18 & 0,00 & 44,19 & 55,81 \\
\hline \multirow{2}{*}{$\begin{array}{l}\text { I do not light candles on the } \\
\text { Holodomor anniversaries } \\
\text { and do not support other } \\
\text { traditions to commemorate } \\
\text { the victims of those times }\end{array}$} & $n$ & 37 & 167 & 338 & 4 & 27 & 105 & 6 & 16 & 21 \\
\hline & $\%$ & 6,83 & 30,81 & 62,36 & 2,94 & 19,85 & 77,21 & 13,95 & 37,21 & 48,84 \\
\hline \multirow{2}{*}{$\begin{array}{l}\text { I do not attend events } \\
\text { dedicated to the Holodomor } \\
\text { commemoration }\end{array}$} & $n$ & 119 & 259 & 164 & 23 & 67 & 46 & 13 & 23 & 7 \\
\hline & $\%$ & 21,96 & 47,79 & 30,26 & 16,91 & 49,26 & 33,82 & 30,23 & 53,49 & 16,28 \\
\hline \multirow{2}{*}{$\begin{array}{l}\text { I avoid thinking and talking } \\
\text { about the Holodomor due to } \\
\text { unpleasant feelings (fear, } \\
\text { oppression, sadness, shame } \\
\text { etc.) }\end{array}$} & $n$ & 26 & 176 & 340 & 5 & 37 & 94 & 4 & 17 & 22 \\
\hline & $\%$ & 4,80 & 32,47 & 62,73 & 3,68 & 27,21 & 69,12 & 9,30 & 39,53 & 51,16 \\
\hline \multirow{2}{*}{$\begin{array}{l}\text { I believe that the theme of } \\
\text { the Holodomor is far- } \\
\text { fetched because hunger and } \\
\text { difficult living conditions } \\
\text { were everywhere }\end{array}$} & $n$ & 8 & 91 & 443 & 0 & 19 & 117 & 2 & 9 & 32 \\
\hline & $\%$ & 1,48 & 16,79 & 81,73 & 0,00 & 13,97 & 86,03 & 4,65 & 20,93 & 74,42 \\
\hline \multirow{2}{*}{$\begin{array}{l}\text { I think that everything was } \\
\text { not so scary as it is being } \\
\text { told now }\end{array}$} & $n$ & 8 & 89 & 445 & 0 & 18 & 118 & 2 & 7 & 34 \\
\hline & $\%$ & 1,48 & 16,42 & 82,10 & 0,00 & 13,24 & 86,76 & 4,65 & 16,28 & 79,07 \\
\hline \multirow{2}{*}{$\begin{array}{l}\text { I think that during the } \\
\text { Holodomor period, those } \\
\text { who suffered were mostly } \\
\text { lazy and alcoholics, those } \\
\text { who did not want to work }\end{array}$} & $n$ & 3 & 88 & 451 & 0 & 15 & 121 & 2 & 6 & 35 \\
\hline & $\%$ & 0,55 & 16,24 & 83,21 & 0,00 & 11,03 & 88,97 & 4,65 & 13,95 & 81,40 \\
\hline \multirow{2}{*}{$\begin{array}{l}\text { I think that during the } \\
\text { Holodomor period, those } \\
\text { who suffered were those } \\
\text { who did not go to the } \\
\text { collective farm and who } \\
\text { refused to work }\end{array}$} & $n$ & 23 & 153 & 366 & 6 & 29 & 101 & 4 & 6 & 33 \\
\hline & $\%$ & 4,24 & 28,23 & 67,53 & 4,41 & 21,32 & 74,26 & 9,30 & 13,95 & 76,74 \\
\hline
\end{tabular}


We note that in the diagnostic section of the interview "Personal attitudes to the Holodomor" (Appendix 1), a two-pole scale is used that includes pairs of statements with opposite meanings. One pole includes statements with meanings of avoidance or devaluation of Holodomor events; the other pole contains statements with meanings of willingness to talk/think about and acknowledge the Holodomor. One example of statements on the two-pole scale is "I avoid conversations on Holodomorrelated topics"- "I talk about Holodomor-related events freely, join in discussing this topic, mention family stories (if they exist)." Respondents had to match the closeness of every statement to their personal behaviour, actions, and beliefs; for example, they could choose one of the following: "Statement on the left is closer to me," "Every statement is partially close," "Statement on the right is closer to me." In Table 5 and in Diagram 1, the data summary has only one pole of meaning, but a second pole that has the opposite meaning is implied.

Diagram 1 shows the data that were summarized for answers "close" and "partially close" for each diagnostic statement with meanings of avoidance or devaluation of the Holodomor events. In Diagram 1, data were integrated that implied full or partial acceptance of tendencies to keep away or undervalue the Holodomor topic by participants. 
Diagram 1. Data integration of answers that imply full or partial closeness of the given statements to participants' behaviour, actions, and beliefs in the analysis of personal attitudes to the Holodomor.

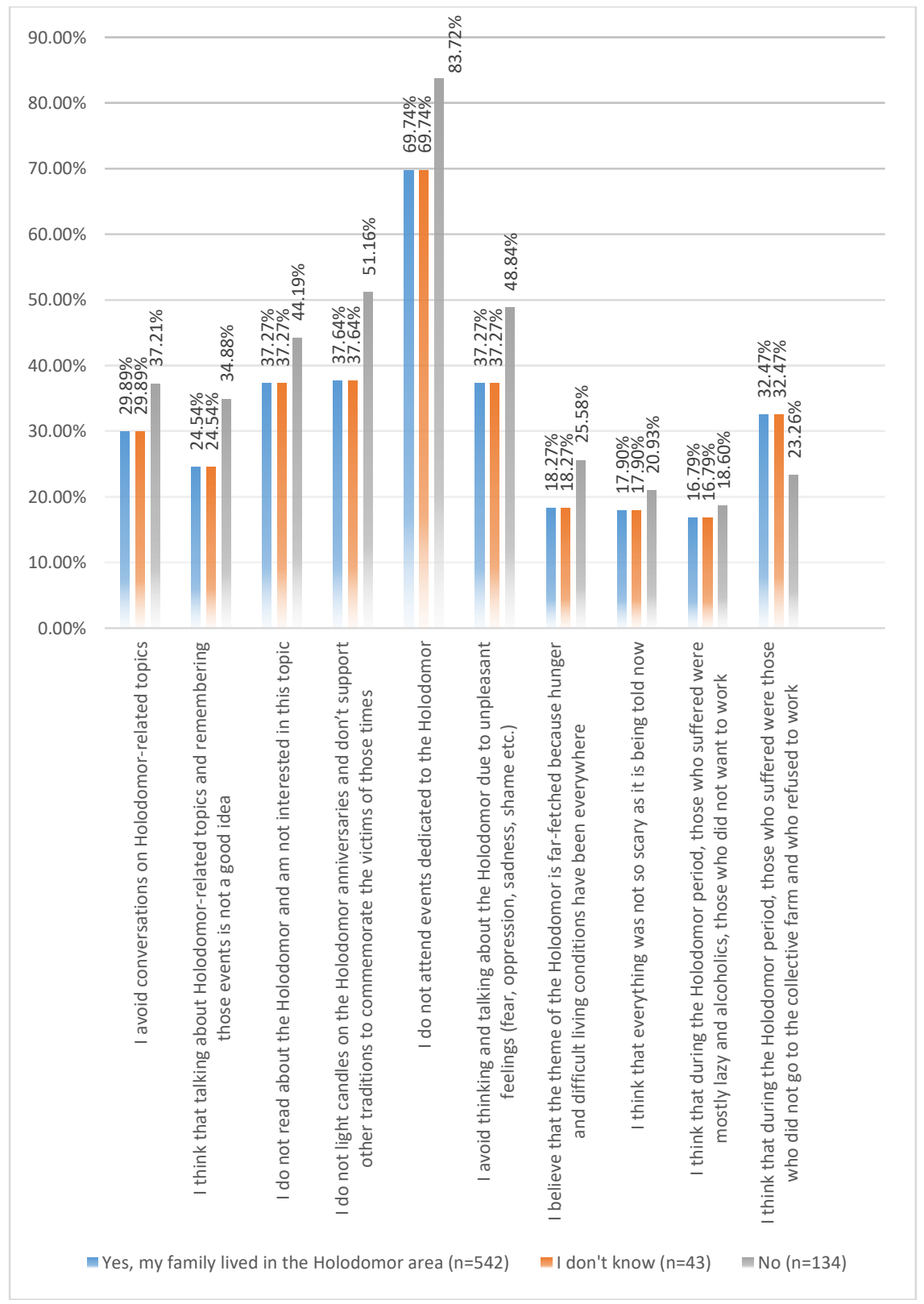


Inverse correlations between personal attitudes and the level of Holodomor-related storytelling behaviour (from the absence of stories to the frequent retelling of stories) prove true for most of the statements. These patterns are presented in Table 6.

Table 6. Correlation between personal attitudes and the level of Holodomor-related storytelling behaviour.

\begin{tabular}{|c|c|c|c|c|c|c|c|c|c|c|c|c|}
\hline \multicolumn{2}{|c|}{$\begin{array}{l}\text { My family } \\
\text { lived in the } \\
\text { Holodomor } \\
\text { area }\end{array}$} & & 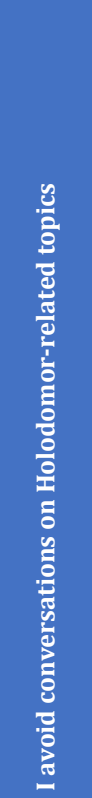 & 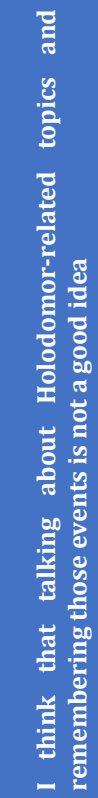 & 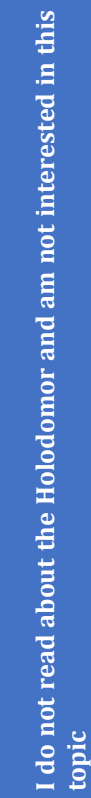 & 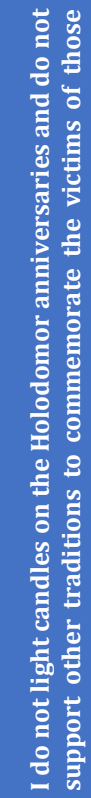 & 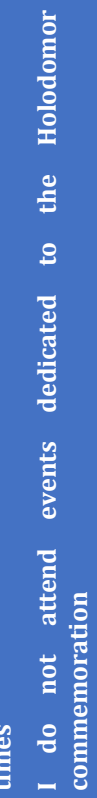 & 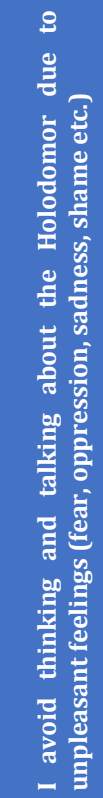 & 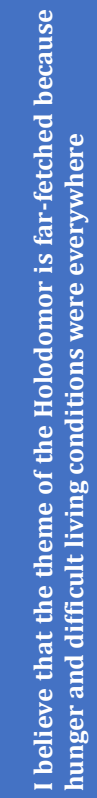 & 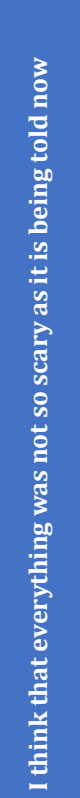 & 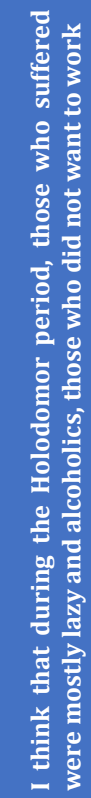 & 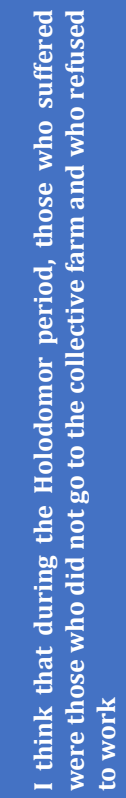 \\
\hline \multirow{6}{*}{ 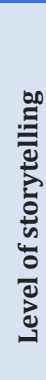 } & \multirow[t]{2}{*}{ Yes } & $r$ & $-0,112$ & $-0,083$ & $-0,137$ & $-0,101$ & $-0,085$ & $-0,038$ & $-0,113$ & $-0,093$ & $-0,110$ & $-0,152$ \\
\hline & & $p$ & 0,009 & 0,053 & 0,001 & 0,018 & 0,048 & 0,373 & 0,009 & 0,030 & 0,010 & 0,000 \\
\hline & \multirow[t]{2}{*}{ No } & $r$ & 0,1 & $-0,000$ & $-0,025$ & $-0,030$ & $-0,023$ & 0,162 & $-0,014$ & 0,026 & 0,124 & 0,078 \\
\hline & & $p$ & 0,248 & 0,999 & 0,772 & 0,723 & 0,790 & 0,060 & 0,869 & 0,762 & 0,152 & 0,369 \\
\hline & I do & $r$ & $-0,206$ & $-0,321$ & $-0,289$ & $-0,388$ & $-0,200$ & $-0,354$ & $-0,305$ & $-0,366$ & $-0,346$ & $-0,193$ \\
\hline & know & $p$ & 0,185 & 0,036 & 0,060 & 0,010 & 0,200 & 0,020 & 0,047 & 0,016 & 0,023 & 0,216 \\
\hline
\end{tabular}


Most of the participants' statements that depict avoidance or devaluation of Holodomor events correlate with the level of storytelling of participants whose families lived on Holodomor-affected territory (exceptions are: "I think that talking about Holodomor-related topics and remembering those events is not a good idea" and "I avoid thinking and talking about the Holodomor due to unpleasant feelings of fear, oppression, sadness, shame"). The same correlations were found in the data derived from participants who do not know where their relatives' resided at the time of the Holodomor (exceptions are: "I avoid talking on Holodomor-related topics" and "I think that during the Holodomor period, those who suffered were those who did not go to the collective farm and who refused to work"). These correlations indicate that the more infrequently Holodomor-related stories are retold in a family, the higher are the negative attitudes toward the Holodomor in the answers of participants.

Such frequency and percentage analyses did not show a significant difference between family worldview attitudes toward the Holodomor and family behavioural strategies in connection with the place of family residence during the Holodomor period. Therefore, we present averaged data for the whole sample (without separating data that include knowledge about ancestors' places of residence during the Holodomor and data that do not include knowledge about ancestors' places of residence during the Holodomor). Table 7 indicates the prevalence of particular attitudes and behaviours in the entire sample.

Table 7. Family worldview attitudes and family behavioural strategies toward the Holodomor.

\begin{tabular}{|c|c|c|c|c|c|c|c|}
\hline & & 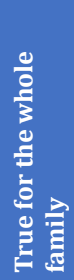 & 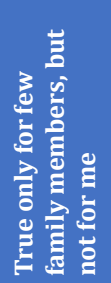 & 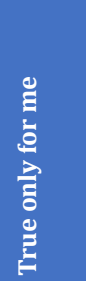 & 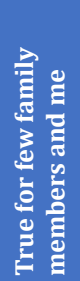 & 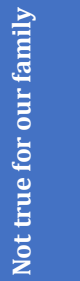 & 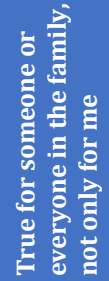 \\
\hline & & 1 & 2 & 3 & 4 & 5 & $1+2+4$ \\
\hline \multirow{2}{*}{$\begin{array}{l}\text { You have to flee from here } \\
\text { because there will not be } \\
\text { anything good }\end{array}$} & $n$ & 41 & 202 & 142 & 82 & 254 & 325 \\
\hline & $\%$ & 5,69 & 28,02 & 19,69 & 11,37 & 35,23 & 45,08 \\
\hline
\end{tabular}


Table 7 continued.

\begin{tabular}{|c|c|c|c|c|c|c|c|}
\hline & & 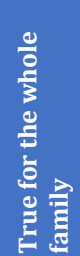 & 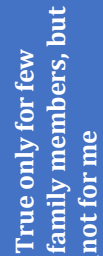 & 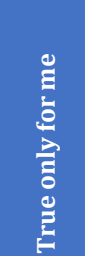 & 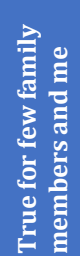 & 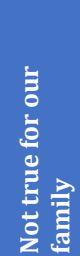 & 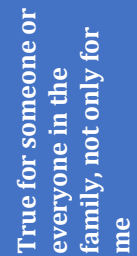 \\
\hline \multirow{2}{*}{$\begin{array}{l}\text { You cannot trust anyone, } \\
\text { especially the authorities }\end{array}$} & $n$ & 192 & 172 & 139 & 133 & 85 & 497 \\
\hline & $\%$ & 26,63 & 23,86 & 19,28 & 18,45 & 11,79 & 68,93 \\
\hline \multirow{2}{*}{$\begin{array}{l}\text { You have to search for a better } \\
\text { life elsewhere }\end{array}$} & $n$ & 53 & 205 & 152 & 73 & 238 & 331 \\
\hline & $\%$ & 7,35 & 28,43 & 21,08 & 10,12 & 33,01 & 45,91 \\
\hline \multirow{2}{*}{$\begin{array}{l}\text { Theft is bad, but if it is at work } \\
\text { or from the state, then I do not } \\
\text { feel strong condemnation }\end{array}$} & $n$ & 32 & 133 & 114 & 23 & 419 & 188 \\
\hline & $\%$ & 4,44 & 18,45 & 15,81 & 3,19 & 58,11 & 26,07 \\
\hline \multirow{2}{*}{$\begin{array}{l}\text { Reporting to a boss about a } \\
\text { colleague who stole something } \\
\text { insignificant at work is not a } \\
\text { good act }\end{array}$} & $n$ & 148 & 87 & 195 & 73 & 218 & 308 \\
\hline & $\%$ & 20,53 & 12,07 & 27,05 & 10,12 & 30,24 & 42,72 \\
\hline \multirow{2}{*}{$\begin{array}{l}\text { It is better to organize and } \\
\text { conduct business with relatives }\end{array}$} & $n$ & 81 & 114 & 150 & 70 & 306 & 265 \\
\hline & $\%$ & 11,23 & 15,81 & 20,80 & 9,71 & 42,44 & 36,75 \\
\hline \multirow{2}{*}{$\begin{array}{l}\text { Children should always be well- } \\
\text { fed }\end{array}$} & $n$ & 408 & 112 & 108 & 51 & 42 & 571 \\
\hline & $\%$ & 56,59 & 15,53 & 14,98 & 7,07 & 5,83 & 79,20 \\
\hline \multirow{2}{*}{$\begin{array}{l}\text { If a child is thin, then, perhaps, } \\
\text { s/he is not feeling well or is } \\
\text { sick-s/he needs to be better } \\
\text { fed }\end{array}$} & $n$ & 120 & 250 & 104 & 37 & 210 & 407 \\
\hline & $\%$ & 16,64 & 34,67 & 14,42 & 5,13 & 29,13 & 56,45 \\
\hline \multirow{2}{*}{$\begin{array}{l}\text { It is better not to interfere in } \\
\text { matters that do not concern you } \\
\text { personally, even when it comes } \\
\text { to crime or dishonesty }\end{array}$} & $n$ & 69 & 187 & 140 & 62 & 263 & 318 \\
\hline & $\%$ & 9,57 & 25,94 & 19,42 & 8,60 & 36,48 & 44,11 \\
\hline \multirow{2}{*}{$\begin{array}{l}\text { If you feel tired, weak, or dizzy, } \\
\text { these are disturbing symptoms } \\
\text { that require an obligatory } \\
\text { medical examination }\end{array}$} & $n$ & 188 & 85 & 161 & 103 & 184 & 376 \\
\hline & $\%$ & 26,07 & 11,79 & 22,33 & 14,29 & 25,52 & 52,15 \\
\hline
\end{tabular}


Table 7 continued.

\begin{tabular}{|c|c|c|c|c|c|c|c|}
\hline & & 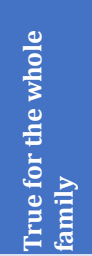 & 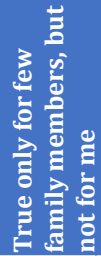 & 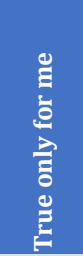 & 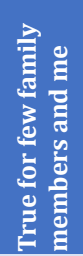 & 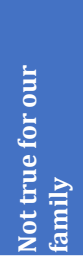 & 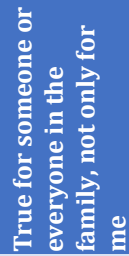 \\
\hline \multirow{2}{*}{$\begin{array}{l}\text { It is wrong and dangerous to } \\
\text { lose weight and be on a diet }\end{array}$} & $n$ & 125 & 152 & 144 & 63 & 237 & 340 \\
\hline & $\%$ & 17,34 & 21,08 & 19,97 & 8,74 & 32,87 & 47,16 \\
\hline \multirow{2}{*}{$\begin{array}{l}\text { You should not throw out bread } \\
\text { and other food leftovers }\end{array}$} & $n$ & 367 & 109 & 103 & 68 & 74 & 544 \\
\hline & $\%$ & 50,90 & 15,12 & 14,29 & 9,43 & 10,26 & 75,45 \\
\hline \multirow{2}{*}{$\begin{array}{l}\text { You have to make food } \\
\text { preserves and always have a } \\
\text { supply of food in the house }\end{array}$} & $n$ & 365 & 135 & 105 & 64 & 52 & 564 \\
\hline & $\%$ & 50,62 & 18,72 & 14,56 & 8,88 & 7,21 & 78,22 \\
\hline \multirow{2}{*}{$\begin{array}{l}\text { You need to have subsistence } \\
\text { farming, grow vegetables, and } \\
\text { plant fruit trees }\end{array}$} & $n$ & 240 & 207 & 122 & 63 & 89 & 510 \\
\hline & $\%$ & 33,29 & 28,71 & 16,92 & 8,74 & 12,34 & 70,74 \\
\hline \multirow{2}{*}{$\begin{array}{l}\text { You have to instruct your } \\
\text { daughters to marry well-to-do } \\
\text { men }\end{array}$} & $n$ & 112 & 161 & 128 & 47 & 273 & 320 \\
\hline & $\%$ & 15,53 & 22,33 & 17,75 & 6,52 & 37,86 & 44,38 \\
\hline \multirow{2}{*}{$\begin{array}{l}\text { You should not go against the } \\
\text { authorities, those who are } \\
\text { above you in the hierarchy }\end{array}$} & $n$ & 46 & 189 & 126 & 42 & 318 & 277 \\
\hline & $\%$ & 6,38 & 26,21 & 17,48 & 5,83 & 44,11 & 38,42 \\
\hline \multirow{2}{*}{$\begin{array}{l}\text { You should not express your } \\
\text { opinion if it is not supported by } \\
\text { the majority }\end{array}$} & $n$ & 49 & 183 & 119 & 37 & 333 & 269 \\
\hline & $\%$ & 6,80 & 25,38 & 16,50 & 5,13 & 46,19 & 37,31 \\
\hline \multirow{2}{*}{$\begin{array}{l}\text { You should not have more } \\
\text { children than you can feed }\end{array}$} & $n$ & 233 & 84 & 180 & 72 & 152 & 389 \\
\hline & $\%$ & 32,32 & 11,65 & 24,97 & 9,99 & 21,08 & 53,95 \\
\hline \multirow{2}{*}{$\begin{array}{l}\text { You have to, first of all, take care } \\
\text { of the well-being of your family }\end{array}$} & $n$ & 323 & 107 & 172 & 67 & 52 & 497 \\
\hline & $\%$ & 44,80 & 14,84 & 23,86 & 9,29 & 7,21 & 68,93 \\
\hline \multirow{2}{*}{$\begin{array}{l}\text { You should not show your } \\
\text { happiness; it is better to share } \\
\text { sorrow with others than joy }\end{array}$} & $n$ & 67 & 151 & 146 & 34 & 323 & 252 \\
\hline & $\%$ & 9,29 & 20,94 & 20,25 & 4,72 & 44,80 & 34,95 \\
\hline
\end{tabular}


The most frequent points cited by participants, which are true for the whole family, are: "Children should always be well-fed" ( $\mathrm{n}=408 ; 56,59 \%)$, "You should not throw out bread and other food leftovers" ( $n=367 ; 50,9 \%)$, and "You have to make food preserves and always have a supply of food in the house" (n=367; 50,62\%). Meanwhile, for the choice "True only for me," only two participants' answers crossed the 25\% line: "You should not have more children than you can feed" ( $n=180 ; 24,97 \%)$ and "Reporting to a boss about a colleague who stole something insignificant at work is not a good act" ( $n=195 ; 27,05 \%)$. Data integration of participant answers that indicated particular attitudes and behaviours of someone or everyone in the family except for or in addition to participants ("True for the whole family," "True only for separate family members, but not for me," "True for separate family members and for me") indicate a set of indexes with high percentages. The following six statements exceeded the 50\% threshold: "You cannot trust anyone, especially the authorities" ( $n=495 ; 68,93 \%)$, "If a child is thin, then, perhaps, s/he is not feeling well or is sick-s/he needs to be better fed" ( $\mathrm{n}=407 ; 56,45 \%)$, "If you feel tired, weak, or dizzy, these are disturbing symptoms that require an obligatory medical examination" ( $n=376$; $52,15 \%)$, "You need to have subsistence farming, grow vegetables, and plant fruit trees" ( $n=510 ; 70,74 \%)$, "You should not have more children than you can feed" ( $n=389 ; 53,95 \%)$, "You have to, first of all, take care of the wellbeing of your family" (n=497; 68,93\%).

\section{DISCUSSION}

This research explores the socio-cultural transmission of post-traumatic stress disorder (PTSD) (according to DSM-5) generated in Ukrainian citizens by the Holodomor in Ukraine (1932-33), and its influence on succeeding generations. We assumed that the avoidance of Holodomor-related storytelling is a diagnostic criterion that can be transferred through generations. We first hypothesized a connection between the kind of suffering experienced by Holodomor victims and the level of Holodomorrelated storytelling behaviour.

Two correlations-between Holodomor storytelling behaviour and the deaths of neighbours or distant relatives $(r=0,22 ; p=0,000)$ and between Holodomor storytelling behaviour and suffering without threat to life ( $\mathrm{r}=-$ $0,16 ; p=0,000)$ - confirm the first hypothesis. It was easier to talk about Holodomor events for individuals who did not have a close relationship with the victims. On the other hand, people who were Holodomor victims themselves tended to keep silent, and that tendency appeared in their offspring. The reasons for this behaviour include a possibility that Holodomor victims suffered from PTSD symptoms. 
Indirect evidence for our first hypothesis is seen in the frequency analysis of Holodomor-related storytelling within families who lived in stricken areas; $84 \%$ of the participants whose families lived in Holodomorstricken areas reported absent or infrequent Holodomor-related storytelling, whereas only $16 \%$ of participants reported frequent and detailed Holodomor-related storytelling. Given that $45 \%$ of participants noted death in the family during the Holodomor and $47 \%$ noted lifethreatening circumstances during the Holodomor, we consider such results to be a socio-cultural transmission of topic avoidance from the Holodomor generation to succeeding generations. These results agree with the studies of Bezo, except in explanation. Bezo writes that the avoidance of trauma is not inherited but is caused by Soviet authority (The Impact of Intergenerational Transmission). We think both reasons can be valid.

Our second research hypothesis is that families avoid discussing Holodomor-related events due to negative attitudes toward this topic. We think that the absence of true information and the presence of Soviet propaganda had significant impacts on awareness of and attitudes toward the Holodomor, and that these attitudes were passed down through generations.

The first proof of the second research hypotheses can be seen in the correlation between the level of Holodomor-related storytelling within families from Holodomor-stricken territories and the attitudes of descendants of Holodomor survivors. Examples of such attitudes are reflected in the following statements: "I believe that the theme of the Holodomor is far-fetched because hunger and difficult living conditions were everywhere" ( $\mathrm{r}=-0,113 ; \mathrm{p}=0,009)$, "I do not read about the Holodomor and am not interested in this topic" $(r=-0,137 ; p=0,000)$, "I do not light candles on the Holodomor anniversaries and do not support other traditions to commemorate the victims of those times" $(r=-0,101 ; p=0,018)$, "I avoid conversations on Holodomor-related topics" ( $r=-0,112$; $p=0,009)$, "I think that during the Holodomor period, those who suffered were mostly lazy and alcoholics, those who did not want to work" ( $r=-0,110 ; p=0,010)$, "I think that during the Holodomor period, those who suffered were those who did not go to the collective farm and who refused to work" ( $\mathrm{r}=-0,152 ; \mathrm{p}=0,010)$. Clearly, people, who have not heard much about the Holodomor, tend to devaluate and dishonour these events in conjunction with Soviet propaganda. The last two attitudes suggest the influence of the propaganda machine, which inculcated such convenient excuses and explanations. From the Soviet point of view, suffering and death were not caused by authorities but were seen as consequences of laziness and refusal to work.

The diversity of answers about personal attitudes within the overall sample also shows results that support the second hypothesis (Table 5). For example, the higher indicators for all negative attitudes (with one exception) 
are shown by participants who do not know about the place of their family residence during the Holodomor. Such lack of knowledge about family can lead to avoidance of the traumatic event. The only attitude that is not in line with others is "I do not read about the Holodomor and do not have interest in this topic." More than half (56\%) of those who do not know about the place of their family residence during the Holodomor evaluated it as distinct from their behaviour, actions, and beliefs. This mean that people feel the lack of such knowledge and are trying to fill in this gap.

In our analysis of personal attitudes toward the Holodomor, we used data integration for answers that implied full or partial closeness of the statements to participants' behaviour, actions, and beliefs (see Appendix). The first reason for this was the presence in participants' answers of complete or partial agreement with avoidance or devaluation of Holodomor events. Another reason could be that respondents tended to answer questions in a socially approved manner. We think that for many participants it was not socially acceptable to agree with statements such as "I do not light candles on the Holodomor anniversaries and do not support other traditions to commemorate the victims of those times" or "I think that during the Holodomor period, those who suffered were mostly lazy and alcoholics who did not want to work." In the pilot version of the interview, the section "Personal attitudes to Holodomor" contained only statements with meanings of avoidance or devaluation toward Holodomor events. There was no opposite pole of statements with meanings of willingness to talk/think and acknowledge the fact of the Holodomor as it is now (see Appendix). Some participants expressed strong dissatisfaction with such question formulation. They were offended by the absence of a positive pole and accused us of having a biased position, although they could have chosen to answer "opposite of me."

The answer "I do not attend events dedicated to the Holodomor commemoration" comprised nearly $70 \%$ of participants whose families lived in the stricken areas and $84 \%$ of participants who did not know the place of residence of their families during the Holodomor. The answer "I do not light candles on the Holodomor anniversaries and do not support other traditions to commemorate the victims of those times" comprised nearly $38 \%$ and $51 \%$ of the same two groups, respectively. The answer "I avoid thinking and talking about the Holodomor due to unpleasant feelings (fear, oppression, sadness, shame, etc.)" comprised nearly $37 \%$ and $49 \%$ of the same two groups. The answer "I do not read about the Holodomor and am not interested in this topic" comprised nearly $37 \%$ and $44 \%$ of the same two groups. The fact that every statement that is made by $30 \%$ or more of participants has an avoidant meaning, supports both our first and second hypotheses.

The absence of the possibility to speak freely about trauma is considered 
to have negative consequences (in the frame of the attachment theory, BarOn, et al.). Bar-On and others write about a "conspiracy of silence," a pattern that would hide past horrors from children and protect parents from painful memories. Silence about the past, however, has a negative impact on parenting and may create an incoherent and lopsided trauma discourse that promotes fear and victimhood and restricts the right to happiness. Bar-On and others also note that silence was not a common pattern among Jewish families after the Holocaust, and that members of freely talking families cope with consequences of the transgenerational trauma more effectively than silent families. Unfortunately, a taboo for sharing a truth effected by the Soviet authority caused collective trauma. Klicperová and others cite this phenomenon as one of the reasons for the post-communist syndrome. They have determined that the civic culture of Czech and Hungarian students has not been much affected by the post-communist syndrome, and have suggested that young age and good education are responsible for this finding (Klicperová et al.). Possibly a study similar to ours, engaging younger participants who grew up in a democratic setting in modern Ukraine and received uncensored (by the Soviet authorities) education, would have more optimistic results.

Negative alterations in cognition, which were present in Holodomor survivors, were also transmitted by family discourse (socio-cultural transmission). Presumably, such alterations in cognition contain themes of food, weight, health, and life-saving, because of the context of the trauma. This consideration is the basis of our third hypothesis, which concerns the widespread worldviews and the behaviour strategies of Holodomor descendants.

During the pilot trial of the questionnaire, participants demanded a larger variety of answers in the diagnostic section "Family Holodomorrelated worldview attitudes and behaviour strategies." The first version of the interview expected participants to match the closeness of the statements "True for my family" or "Not true for my family" to behaviour, actions, and beliefs they observe in their families. The final version of the questionnaire included five options: "True for the whole family," "True only for a few family members, but not for me," "True for a few family members and for me," "Not true for my family," and "True only for me." As we are primarily concerned with the content of family discourse, one of the analysis steps was data integration of answers that indicate that the studied attitudes take place in the family. This analysis step concerns every answer noted above except the last, "True only for me." Data for this answer was not summarized with data for the other answers because of its disconnection with the transgenerational context; that is, it is valid for the participant but not for other family members. This data integration is shown in Table 7 under the 
heading "True for someone or everyone in the family, not only for me," and later in brackets near every statement.

The most prominent discourse theme is food because food shortage was the most traumatic situation during the Holodomor: good feeding"Children should always be well-fed" (n=571; 79\%-here and below, data integration for answers that indicate that the studied attitudes take place in the family), food preserving- "You have to make food preserves and always have a supply of food in the house" ( $n=564 ; 78 \%)$, food saving and caretaking- "You should not throw out bread and other food leftovers" ( $\mathrm{n}=544 ; 76 \%)$, food cultivation-“You need to have subsistence farming, grow vegetables, and plant fruit trees" (n=510; 71\%). During the Holodomor, Ukrainians did not have sufficient food for survival and a healthy life. Food centration is a specific characteristic of Ukrainian daily life and is noted by many cultural studies scholars and regular observers. It is also described in Bezo's dissertation as a behavioural shift in the direction of food.

It is important to note that worldview attitudes and behaviour strategies that are held by nearly $50 \%$ of survey participants are connected to traumatic factors of the Holodomor. Their statements can be categorized following Masliuk's classification of the depressive factors of the Holodomor. Information deprivation is detrimental to a positive worldview, as seen in the response, "You cannot trust anyone, especially the authorities" ( $n=497$; 69\%). Living space limitation can impact worldviews and relevant behaviour strategies: "You have to flee from here because there will not be anything good" $(n=325 ; 45 \%)$, "You have to search for a better life elsewhere" ( $n=341 ; 46 \%)$, "You should not have more children than you can feed" ( $n=389 ; 54 \%)$. Destruction of traditions (one of the strongest among which was the tradition of mutual help and support) may well be the trigger for: "You have to, first of all, take care of the well-being of your family" $(n=497 ; 69 \%)$, "It is better not to interfere in matters that do not concern you personally, even when it comes to crime or dishonesty" ( $n=318 ; 45 \%)$.

But even taking into account the contextual connections between traumatic factors of the Holodomor, we cannot say that all worldview attitudes and behavioural strategies were caused only by the Holodomor. Klicperová writes that Soviet historical impacts and concomitant propaganda distorted the moral and psychological health of Czech and Hungarian citizens. The same can be said about Ukrainians, who have suffered a number of traumatic events in their history, mostly during the Soviet period. In the context of state terror, there were de-kulakization and collectivization, deportation and displacements, mass arrests and violence. This issue is a limitation of our study and needs further exploration. Another limitation concerns the work with the study sample. It was analyzed without distinctions regarding the age, place of residence, life experience, and socio- 
cultural context of each participant. Future research could consider Holodomor-related worldview attitudes and behavioural strategies using tools like content-analysis or factor-analysis.

\section{CONCLUSION}

This study of psychological consequences of the Holodomor famine in Ukraine focused on current personal attitudes and behavioural strategies that connect Holodomor exposure with Ukrainian family experience. The research model postulates that the PTSD symptoms of Holodomor victims had significant psychological consequences on subsequent generations.

The most prominent research results are (a) the avoidance of speaking about the Holodomor is more common among families whose ancestors suffered from traumatic events; (b) negative personal attitudes to the Holodomor (avoidance and devaluation of Holodomor-related topics and actions) are present among individuals who do not know much about the traumatic events during the Hololomor; (c) the most widespread Holodomor-related worldview attitudes and behavioural strategies within families correspond to trauma-related themes such as child and family feeding patterns, preservation of food and supplies, distrust of authorities, disappointment in the government, and importance of family needs versus community needs.

The most important theoretical implication of this study is that sociocultural transmission is a possible avenue for the development of psychological consequences of transgenerational traumas. The main practical implication is that truthful trauma-focused storytelling (within families and within societies that have traumatic events in common) can decrease the psychological consequences of transgenerational traumas. 


\section{Works Cited}

Ahmadzadeh, G., and A. Malekian. "Aggression, Anxiety and Social Development in Adolescent Children of War Veterans with PTSD Versus Those of Non-Veterans." Journal of Research in Medical Sciences, no. 9, 2004, pp. 33-36.

American Psychiatric Association. Diagnostic and Statistical Manual of Mental Disorders (DSM-5). 5th ed., American Psychiatric Pub, 2013.

Baranowsky, Anna B., et al. "PTSD Transmission: A Review of Secondary Traumatization in Holocaust Survivor Families." Canadian Psychology, vol. 39, no. 4, 1998, pp. 247-56. DOI: 10.1037/h0086816

Bar-On, Dan, et al. "Multigenerational Perspectives on Coping with the Holocaust Experience: An Attachment Perspective for Understanding the Developmental Sequelae of Trauma across Generations." International Journal of Behavioral Development, vol. 22, no. 2, 1998, pp. 315-38. DOI: 10.1080/016502598384397

Bezo, Brent John Louis. The Impact of Intergenerational Transmission of Trauma from the Holodomor Genocide of 1932-1933 in Ukraine. 2011. Carleton University, $\mathrm{PhD}$ dissertation.

Bezo, Brent, and Stefania Maggi. "The Intergenerational Impact of the Holodomor Genocide on Gender Roles, Expectations and Performance: The Ukrainian Experience." Annals of Psychiatry and Mental Health, vol. 3, no 3, 2015, pp. 1-4.

---. "Intergenerational Perceptions of Mass Trauma's Impact on Physical Health and Well-Being." Psychological Trauma: Theory, Research, Practice, and Policy, vol. 10, no. 1, 2018, pp. 87-94. DOI: $10.1037 /$ tra0000284

---. "Living in 'Survival Mode:' Intergenerational Transmission of Trauma from the Holodomor Genocide of 1932-1933 in Ukraine." Social Science \& Medicine, vol. 134, 2015, pp. 87-94. DOI: 10.1016/j.socscimed.2015.04.009

Bilinsky, Yaroslav. "Was the Ukrainian Famine of 1932-1933 Genocide?" Journal of Genocide Research, vol. 1, no. 2, 1999, pp. 147-56. DOI: $10.1080 / 14623529908413948$

Bryant, Richard A., et al. "The Effect of Post-Traumatic Stress Disorder on Refugees' Parenting and Their Children's Mental Health: A Cohort Study." The Lancet Public Health, vol. 3, no. 5, 2018, pp. e249-e58. DOI: 10.1016/S24682667(18)30051-3

DeGruy Leary, Joy. Post-Traumatic Slave Syndrome: America's Legacy of Enduring Injury. Uptone Press, 2005.

Field, Nigel P., et al. "Parental Styles in the Intergenerational Transmission of Trauma Stemming from the Khmer Rouge Regime in Cambodia." American Journal of Orthopsychiatry, vol. 83, no. 4, 2013, pp. 483-94. DOI: 10.1111/ajop.12057

Flory, Janine D. et al. "Maternal Exposure to the Holocaust and Health Complaints in Offspring." Disease Markers, vol. 30, nos. 2-3, 2011, pp. 133-39. DOI: 10.3233/DMA-2011-0748.

Hornostai, Pavlo. "Kolektyvna travma ta hrupova identychnist'." Psykholohichni perspektyvy, no. 2, 2012, pp. 89-95.

Hrydkovets', Liudmyla. "Vplyv rodynnoi determinanty na podolannia osobystisnykh kryz." Science and Education a New Dimension. Pedagogy and Psychology, vol. II(10), no. 20, 2014, pp. 114-17.

Kellermann, Natan P. F. “Epigenetic Transmission of Holocaust Trauma: Can 
Nightmares Be Inherited." The Israel Journal of Psychiatry and Related Sciences, vol. 50, no. 1, 2013, pp. 33-39.

---. "Transmission of Holocaust Trauma-An Integrative View." Psychiatry: Interpersonal and Biological Processes, vol. 64, no. 3, 2001, pp. 256-67. DOI: 10.1521/psyc.64.3.256.18464

Klain, Eduard, and Ladislav Pavić. "Psychotrauma and Reconciliation." Croatian Medical Journal, vol. 43, no. 2, 2002, pp. 126-37.

Klicperová-Baker, Martina. Post-Communist Syndrome. Open Society Institute, 1999.

Klicperová, Martina, et al. "In the Search for a Post-Communist Syndrome: A Theoretical Framework and Empirical Assessment." Journal of Community \& Applied Social Psychology, vol. 7, no. 1, 1997, pp. 39-52. DOI: 10.1002/(SICI)1099-1298(199702)7:1<39::AID-CASP398>3.0.CO;2-1

Lev-Wiesel, Rachel. "Intergenerational Transmission of Trauma across Three Generations: A Preliminary Study." Qualitative Social Work, vol. 6, no. 1, 2007, pp. 75-94. DOI: $10.1177 / 1473325007074167$

Masliuk, Andrii. "Riznovydy depryvuiuchykh chynnykiv podii holodomoriv v Ukraini pershoi polovyny XX stolittia.” Naukovi zapysky Instytutu psykholohii imeni H. S. Kostiuka, no. 38, 2010, pp. 238-46.

National Museum of http://memorialholodomor.org.ua/eng. Accessed 26 Apr. 2020.

Noriega, Gloria. "Transgenerational Scripts: The Unknown Knowledge.” Life Scripts: A Transactional Analysis of Unconscious Relational Patterns, edited by Richard G. Erskine, Routledge, 2010, pp. 269-90.

Obushnyi, Mykola, and Tetiana Voropaieva. "Polityko-psykholohichni aspekty Holodomoru 1932-1933 rokiv." Sotsial'na psykholohiia, no. 2, 2009, pp. 39-48.

Palosaari, Esa, et al. "Intergenerational Effects of War Trauma among Palestinian Families Mediated via Psychological Maltreatment." Child Abuse \& Neglect, vol. 37, no. 11, 2013, pp. 955-68. DOI: 10.1016/j.chiabu.2013.04.006

Reva, Iryna. Po toi bik sebe: sotsial'no-psykholohichni i kul'turni naslidky Holodomoru ta stalins'kykh represii. A. L. Svidler, 2013.

Rieder, Heide, and Thomas Elbert. "Rwanda-Lasting Imprints of a Genocide: Trauma, Mental Health and Psychosocial Conditions in Survivors, Former Prisoners and Their Children." Conflict and Health, vol. 7, no. 1, 2013, p. 6. DOI: 10.1186/1752-1505-7-6

Rosenheck, Robert, and Jane Thomson. “'Detoxification' of Vietnam War Trauma: A Combined Family-Individual Approach." Family Process, vol. 25, no. 4, 1986, pp. 559-70. DOI: 10.1111/j.1545-5300.1986.00559.x

Rowland-Klein, Dani, and Rosemary Dunlop. "The Transmission of Trauma across Generations: Identification with Parental Trauma in Children of Holocaust Survivors." Australian \& New Zealand Journal of Psychiatry, vol. 32, no. 3, 1998, pp. 358-69. DOI: 10.3109/00048679809065528

Schutzenberger, Anne Ancelin. The Ancestor Syndrome: Transgenerational Psychotherapy and the Hidden Links in the Family Tree. Routledge, 2014.

Skelton, Kelly, et al. "PTSD and Gene Variants: New Pathways and New Thinking." Neuropharmacology, vol. 62, no. 2, 2012, pp. 628-37. DOI: 10.1016/j.neuropharm.2011.02.013 
Sysyn, Frank. "Thirty Years of Research on the Holodomor: A Balance Sheet." East/West: Journal of Ukrainian Studies, vol. 2, no. 1, 2015, pp. 3-16. DOI: 10.21226/T26P4M

Yehuda, Rachel, and Amy Lehrner. "Intergenerational Transmission of Trauma Effects: Putative Role of Epigenetic Mechanisms." World Psychiatry, vol. 17, no. 3, 2018, pp. 243-57. DOI: 10.1002/wps.20568

Yehuda, Rachel, et al. "Childhood Trauma and Risk for PTSD: Relationship to Intergenerational Effects of Trauma, Parental PTSD, and Cortisol Excretion." Development and Psychopathology, vol. 13, no. 3, 2001, pp. 733-53. DOI: $10.1017 / \mathrm{s} 0954579401003170$ 


\section{Appendix}

\section{The Psychological Consequences of the Holodomor in Ukraine}

Instructions. This questionnaire aims to investigate the psychological consequences of the Holodomor, the 1932-33 famine that was purposefully organized on the territory of Soviet Ukraine by the Soviet authorities. We ask you to answer questions that will help establish beliefs and strategies that may be related to the Holodomor events. Thank you for participation!

The data are collected within the framework of the research project, supported by the Holodomor Research and Education Consortium (HREC) and the Canadian Institute of Ukrainian Studies.

\section{Holodomor-related family history}

Please choose the answer that best corresponds to your family history

\begin{tabular}{|c|c|c|c|c|}
\hline & Yes & No & $\begin{array}{l}\text { I do not } \\
\text { know }\end{array}$ & Other \\
\hline $\begin{array}{l}\text { My family lived in the Holodomor } \\
\text { area }\end{array}$ & & & & \\
\hline $\begin{array}{l}\text { One or more of my family members } \\
\text { died during the Holodomor }\end{array}$ & & & & \\
\hline $\begin{array}{l}\text { All my family members survived } \\
\text { during Holodomor but starved and } \\
\text { suffered a lot }\end{array}$ & & & & \\
\hline $\begin{array}{l}\text { Our neighbours/distant relatives } \\
\text { suffered or died during the } \\
\text { Holodomor }\end{array}$ & & & & \\
\hline $\begin{array}{l}\text { My family starved during the } \\
\text { Holodomor, but not so much that it } \\
\text { threatened their life }\end{array}$ & & & & \\
\hline $\begin{array}{l}\text { My family experienced no suffering } \\
\text { from the Holodomor }\end{array}$ & & & & \\
\hline
\end{tabular}




\section{Holodomor-related storytelling behaviour within the family}

Please choose the answer that best corresponds to your personal experience

\begin{tabular}{|l|l|}
\hline Holodomor-related family stories were retold often and in detail \\
\hline Holodomor-related family stories were retold but not often & \\
\hline $\begin{array}{l}\text { Holodomor-related family stories exist but were not retold; I } \\
\text { learned about them from friends or other relatives }\end{array}$ & $\begin{array}{l}\text { I know nothing about Holodomor-related family stories; I found out } \\
\text { about the Holodomor events from the media, books, articles, etc. }\end{array}$ \\
\hline I know for sure that there are no Holodomor-related family stories & \\
\hline Another answer: & \\
\hline
\end{tabular}

\section{Personal attitudes to Holodomor}

Please match the closeness of the statement to your behaviour, actions, and beliefs

\begin{tabular}{|c|c|c|c|c|}
\hline & $\begin{array}{l}\text { Statement on } \\
\text { the left is } \\
\text { closer to me }\end{array}$ & $\begin{array}{l}\text { Every } \\
\text { statement } \\
\text { is partially } \\
\text { close }\end{array}$ & $\begin{array}{l}\text { Statement } \\
\text { on the right } \\
\text { is closer to } \\
\text { me }\end{array}$ & \\
\hline $\begin{array}{l}\text { I avoid } \\
\text { conversations on } \\
\text { Holodomor- } \\
\text { related topics }\end{array}$ & & & & $\begin{array}{l}\text { I talk about } \\
\text { Holodomor-related } \\
\text { events freely, join in } \\
\text { discussing this topic, } \\
\text { mention family } \\
\text { stories (if they exist) }\end{array}$ \\
\hline $\begin{array}{l}\text { I think that } \\
\text { talking about } \\
\text { Holodomor- } \\
\text { related topics and } \\
\text { remembering } \\
\text { those events is } \\
\text { not a good idea }\end{array}$ & & & & $\begin{array}{l}\text { I think that the topic } \\
\text { of the Holodomor } \\
\text { should be discussed, } \\
\text { events should be } \\
\text { mentioned, } \\
\text { information should } \\
\text { be disseminated }\end{array}$ \\
\hline $\begin{array}{l}\text { I do not read } \\
\text { about the } \\
\text { Holodomor and } \\
\text { am not interested } \\
\text { in this topic }\end{array}$ & & & & $\begin{array}{l}\text { I try to find out more } \\
\text { about Holodomor- } \\
\text { related events, to } \\
\text { read different } \\
\text { sources, to explore } \\
\text { my family history }\end{array}$ \\
\hline
\end{tabular}




\section{Personal attitudes to Holodomor cont.}

\begin{tabular}{|c|c|c|c|c|}
\hline & $\begin{array}{l}\text { Statement } \\
\text { on the left } \\
\text { is closer } \\
\text { to me }\end{array}$ & $\begin{array}{l}\text { Every } \\
\text { statement } \\
\text { is partially } \\
\text { close }\end{array}$ & $\begin{array}{l}\text { Statement } \\
\text { on the } \\
\text { right is } \\
\text { closer to } \\
\text { me }\end{array}$ & \\
\hline $\begin{array}{l}\text { I do not light } \\
\text { candles on the } \\
\text { Holodomor } \\
\text { anniversaries and } \\
\text { do not support } \\
\text { other traditions to } \\
\text { commemorate the } \\
\text { victims of those } \\
\text { times }\end{array}$ & & & & $\begin{array}{l}\text { I commemorate } \\
\text { the Holodomor } \\
\text { victims and try to } \\
\text { follow the } \\
\text { traditions }\end{array}$ \\
\hline $\begin{array}{l}\text { I do not attend } \\
\text { events dedicated } \\
\text { to the Holodomor } \\
\text { commemoration }\end{array}$ & & & & $\begin{array}{l}\text { I am trying to } \\
\text { follow and, if } \\
\text { possible, attend } \\
\text { events dedicated } \\
\text { to the Holodomor } \\
\text { commemoration }\end{array}$ \\
\hline $\begin{array}{l}\text { I avoid thinking } \\
\text { and talking about } \\
\text { the Holodomor } \\
\text { due to unpleasant } \\
\text { feelings (fear, } \\
\text { oppression, } \\
\text { sadness, shame } \\
\text { etc.) }\end{array}$ & & & & $\begin{array}{l}\text { I fully cope with } \\
\text { the feelings that } \\
\text { arise during my } \\
\text { discussion of } \\
\text { Holodomor } \\
\text { events and the } \\
\text { mention of them }\end{array}$ \\
\hline $\begin{array}{l}\text { I believe that the } \\
\text { theme of the } \\
\text { Holodomor is far- } \\
\text { fetched because } \\
\text { hunger and } \\
\text { difficult living } \\
\text { conditions were } \\
\text { everywhere }\end{array}$ & & & & $\begin{array}{l}\text { I have confidence } \\
\text { that the } \\
\text { Holodomor } \\
\text { problem is real } \\
\text { and that the } \\
\text { events of that } \\
\text { time have } \\
\text { seriously affected } \\
\text { the lives and } \\
\text { psychology of } \\
\text { Ukrainians }\end{array}$ \\
\hline
\end{tabular}




\section{Personal attitudes to Holodomor cont.}

\begin{tabular}{|c|c|c|c|c|}
\hline & $\begin{array}{l}\text { Statement } \\
\text { on the left } \\
\text { is closer } \\
\text { to me }\end{array}$ & $\begin{array}{l}\text { Every } \\
\text { statement } \\
\text { is partially } \\
\text { close }\end{array}$ & $\begin{array}{l}\text { Statement } \\
\text { on the } \\
\text { right is } \\
\text { closer to } \\
\text { me }\end{array}$ & \\
\hline $\begin{array}{l}\text { I think that } \\
\text { everything was } \\
\text { not so scary as it } \\
\text { is being told now }\end{array}$ & & & & $\begin{array}{l}\text { I believe that the } \\
\text { Holodomor } \\
\text { events were } \\
\text { deliberately } \\
\text { provoked and } \\
\text { they really are a } \\
\text { genocide of the } \\
\text { Ukrainian people }\end{array}$ \\
\hline $\begin{array}{l}\text { I think that during } \\
\text { the Holodomor } \\
\text { period, those who } \\
\text { suffered were } \\
\text { mostly lazy and } \\
\text { alcoholics, those } \\
\text { who did not want } \\
\text { to work }\end{array}$ & & & & $\begin{array}{l}\text { I think that } \\
\text { everyone suffered } \\
\text { during the } \\
\text { Holodomor, } \\
\text { regardless of } \\
\text { industriousness }\end{array}$ \\
\hline $\begin{array}{l}\text { I think that during } \\
\text { the Holodomor } \\
\text { period, those who } \\
\text { suffered were } \\
\text { those who did not } \\
\text { go to the } \\
\text { collective farm } \\
\text { and who refused } \\
\text { to work }\end{array}$ & & & & $\begin{array}{l}\text { I think that } \\
\text { everyone suffered } \\
\text { during the } \\
\text { Holodomor, } \\
\text { regardless of the } \\
\text { willingness to } \\
\text { work in collective } \\
\text { farms and state } \\
\text { farms }\end{array}$ \\
\hline
\end{tabular}


Family worldview attitudes and family behavioural strategies toward the Holodomor

Please match the closeness of the statement to behaviour, actions and beliefs in your family

\begin{tabular}{|c|c|c|c|c|c|}
\hline & $\begin{array}{l}\text { True for } \\
\text { the whole } \\
\text { family }\end{array}$ & $\begin{array}{l}\text { True only } \\
\text { for few } \\
\text { family } \\
\text { members, } \\
\text { but not for } \\
\text { me }\end{array}$ & $\begin{array}{l}\text { True } \\
\text { only } \\
\text { for } \\
\text { me }\end{array}$ & $\begin{array}{l}\text { True for } \\
\text { few family } \\
\text { members } \\
\text { and me }\end{array}$ & $\begin{array}{l}\text { Not true } \\
\text { for my } \\
\text { family }\end{array}$ \\
\hline $\begin{array}{l}\text { You have to flee from } \\
\text { here because there will } \\
\text { not be anything good }\end{array}$ & & & & & \\
\hline $\begin{array}{l}\text { You cannot trust } \\
\text { anyone, especially } \\
\text { authorities }\end{array}$ & & & & & \\
\hline $\begin{array}{l}\text { You have to search for a } \\
\text { better life elsewhere }\end{array}$ & & & & & \\
\hline $\begin{array}{l}\text { Theft is bad, but if it is } \\
\text { at work or from the } \\
\text { state, then I do not feel } \\
\text { strong condemnation }\end{array}$ & & & & & \\
\hline $\begin{array}{l}\text { Reporting to a boss } \\
\text { about a colleague who } \\
\text { stole something } \\
\text { insignificant at work is } \\
\text { not a good act }\end{array}$ & & & & & \\
\hline $\begin{array}{l}\text { It is better to organize } \\
\text { and conduct business } \\
\text { with relatives }\end{array}$ & & & & & \\
\hline $\begin{array}{l}\text { Children should always } \\
\text { be well-fed }\end{array}$ & & & & & \\
\hline $\begin{array}{l}\text { If a child is thin, then, } \\
\text { perhaps, s/he is not } \\
\text { feeling well or is sick- } \\
\text { s/he needs to be better } \\
\text { fed }\end{array}$ & & & & & \\
\hline
\end{tabular}


Family worldview attitudes and family behavioural strategies toward the Holodomor cont.

\begin{tabular}{|c|c|c|c|c|c|}
\hline & $\begin{array}{l}\text { True for } \\
\text { the whole } \\
\text { family }\end{array}$ & $\begin{array}{l}\text { True only } \\
\text { for few } \\
\text { family } \\
\text { members, } \\
\text { but not for } \\
\text { me }\end{array}$ & $\begin{array}{l}\text { True } \\
\text { only } \\
\text { for } \\
\text { me }\end{array}$ & $\begin{array}{l}\text { True for } \\
\text { few family } \\
\text { members } \\
\text { and me }\end{array}$ & $\begin{array}{l}\text { Not true } \\
\text { for my } \\
\text { family }\end{array}$ \\
\hline $\begin{array}{l}\text { It is better not to } \\
\text { interfere in matters } \\
\text { that do not concern you } \\
\text { personally, even when } \\
\text { it comes to crime or } \\
\text { dishonesty }\end{array}$ & & & & & \\
\hline $\begin{array}{l}\text { If you feel tired, weak, } \\
\text { or dizzy, these are } \\
\text { disturbing symptoms } \\
\text { that require an } \\
\text { obligatory medical } \\
\text { examination }\end{array}$ & & & & & \\
\hline $\begin{array}{l}\text { It is wrong and } \\
\text { dangerous to lose } \\
\text { weight and be on a diet }\end{array}$ & & & & & \\
\hline $\begin{array}{l}\text { You should not throw } \\
\text { out bread and other } \\
\text { food leftovers }\end{array}$ & & & & & \\
\hline $\begin{array}{l}\text { You have to make food } \\
\text { preserves and always } \\
\text { have a supply of food in } \\
\text { the house }\end{array}$ & & & & & \\
\hline $\begin{array}{l}\text { You need to have } \\
\text { subsistence farming, } \\
\text { grow vegetables, and } \\
\text { plant fruit trees }\end{array}$ & & & & & \\
\hline $\begin{array}{l}\text { You have to instruct } \\
\text { your daughters to } \\
\text { marry well-to-do men }\end{array}$ & & & & & \\
\hline
\end{tabular}


Family worldview attitudes and family behavioural strategies toward the Holodomor cont.

\begin{tabular}{|c|c|c|c|c|c|}
\hline & $\begin{array}{l}\text { True for } \\
\text { the whole } \\
\text { family }\end{array}$ & $\begin{array}{l}\text { True only } \\
\text { for few } \\
\text { family } \\
\text { members, } \\
\text { but not for } \\
\text { me }\end{array}$ & $\begin{array}{l}\text { True } \\
\text { only } \\
\text { for } \\
\text { me }\end{array}$ & $\begin{array}{l}\text { True for } \\
\text { few family } \\
\text { members } \\
\text { and me }\end{array}$ & $\begin{array}{l}\text { Not true } \\
\text { for my } \\
\text { family }\end{array}$ \\
\hline $\begin{array}{l}\text { You should not go } \\
\text { against the authorities, } \\
\text { those who are above } \\
\text { you in the hierarchy }\end{array}$ & & & & & \\
\hline $\begin{array}{l}\text { You should not express } \\
\text { your opinion if it is not } \\
\text { supported by the } \\
\text { majority }\end{array}$ & & & & & \\
\hline $\begin{array}{l}\text { You should not have } \\
\text { more children than you } \\
\text { can feed }\end{array}$ & & & & & \\
\hline $\begin{array}{l}\text { You have to, first of all, } \\
\text { take care of the well- } \\
\text { being of your family }\end{array}$ & & & & & \\
\hline $\begin{array}{l}\text { You should not show } \\
\text { your happiness; it is } \\
\text { better to share sorrow } \\
\text { with others than joy }\end{array}$ & & & & & \\
\hline
\end{tabular}

Please add a description of any family behaviour, actions, and beliefs that, in your opinion, can be Holodomor-related

\section{Information about the survey participants}

\begin{tabular}{|l|l|}
\hline \hline Please indicate your age & \\
\hline Please indicate your gender & \\
\hline Please indicate your current residence & \\
\hline $\begin{array}{l}\text { Please indicate your family's place of residence during } \\
\text { the Holodomor }\end{array}$ & \\
\hline
\end{tabular}

